\title{
ASSESSMENT AND SELF-ASSESSMENT OF CORPORATE SOCIAL RESPONSIBILITY: PROBLEMS AND DECISIONS
}

\author{
Larisa NIKITINA \\ Voronezh State University, Universitetskaya pl., 1, Voronezh, Russia, 394006. E-mail: lanikitina @yandex.ru
}

Accepted 20 November, 2012

\begin{abstract}
Currently, the requirements for the social side of the enterprise are increasingly growing. It applies to businesses of all types of ownership, size, organizational and legal forms, regardless of their geographical location, type of activity, cultural and national traditions. In Russia, after extensive discussion of CSR essence in the last decade, the situation has been stabilized. Further extension of CSR is largely hindered by the lack of clear and accessible teaching approaches to organizing and implementing social activities in the enterprises of the region, based on certain rules and requirements. One of the attributes of socially responsible behavior of companies is to follow certain standards, since they are the main tool to assess the stakeholders and also allows the company to objectively present their own level to achieve socially important parameters of development. In 2011, the author participated in the development of the "Standard of Corporate Social Responsibility of Enterprises of Voronezh Region", which laid the evaluation indicators of the regional specificity. In this paper, the technique of self-assessment of corporate social responsibility based on the construction of the results matrix in the spheres of responsibility and stakeholder engagement is represented.
\end{abstract}

Keywords: Corporate Social Responsibility, Indicator, Social Accountability, Results Matrix, Standard.

\section{INTRODUCTION}

In Russia, for the moment the number of companies that systematically carries out activities in all areas of CSR is very small. Even fewer companies are able to formalize the management of CSR and social reporting which are provided on a regular basis. We believe that this is a manifestation of such institutional feature of Russian society as dominance of the informal part organization, which in turn has led to some skepticism of Russian businessmen on the need for formal documents, regulating the social and economic activities. Therefore, one of the major problems faced by researchers and practitioners is the measurement of corporate social performance and interpretation of results obtained in accordance to the values of society and companies.

Large Russian companies which actively cooperate with foreign companies commonly use international standards. However, for the evaluation of most small and medium-sized enterprises these standards are not suitable enough precisely because of the orientation of the transnational and large national businesses. In addition, the appreciation of these standards is very limited: the results of the regional empirical studies showed that only a few of the respondents are familiar in general terms with international accounting standards in the field of CSR, knowing the details of these standards was not among the respondents (Nikitina, 2009). Tables $1,2,3$ present data on the use of social reporting in the formation of CSR.

As one can see, social reports are compiled by only 6-10\% of Voronezh enterprises. In the period of favourable business conditions, $23.3 \%$ of managers planned to start the process, but during the worsening economic situation only $2 \%$ of respondents kept the desire. In other words, Russian managers do not consider the CSR reports as important statements of their economic well-being.

It should be noted that the surveyed managers did not make separate social reports. In 2007, $100 \%$ of the respondents indicated the appendix to the annual report as a form of social reporting, in 2009 a third of managers made statements in the media. 
Table 1: The annual social reports preparation (\% of respondents)

\begin{tabular}{|l|c|c|}
\hline \multirow{2}{*}{ Compilation of reports of social } & \multicolumn{2}{|c|}{ Years } \\
\cline { 2 - 3 } & $\mathbf{2 0 0 7}$ & $\mathbf{2 0 0 9}$ \\
\hline Yes & 10,0 & 6,0 \\
\hline No, but plan & 23.3 & 2,0 \\
\hline No & 66,7 & 92,0 \\
\hline
\end{tabular}

Table 2: Forms of social reporting (\% of companies that make up social reports)

\begin{tabular}{|l|c|c|}
\hline \multirow{2}{*}{ The form of social reporting } & \multicolumn{2}{|c|}{ Years } \\
\cline { 2 - 3 } & $\mathbf{2 0 0 7}$ & $\mathbf{2 0 0 9}$ \\
\hline A separate report in accordance with international non-standard & 0,0 & 0,0 \\
\hline Appendix to the Annual Report & 100,0 & 66.7 \\
\hline Report to the board & 0,0 & 0,0 \\
\hline Speech in the Media & 0,0 & 33.3 \\
\hline Other & 0,0 & 0,0 \\
\hline
\end{tabular}

Table 3: Reasons for not making social reports (\% of companies that do not make up social reports)

\begin{tabular}{|l|c|c|}
\hline \multirow{2}{*}{\multicolumn{1}{|c|}{ Reasons }} & \multicolumn{2}{c|}{ Years } \\
\cline { 2 - 3 } & $\mathbf{2 0 0 7}$ & $\mathbf{2 0 0 9}$ \\
\hline Other tasks & 48.1 & 29.8 \\
\hline The company is not ready for dialogue with the public & 14.8 & 4.3 \\
\hline Lack of financial resources & 11.1 & 10.6 \\
\hline Necessity absence & 26.0 & 46.8 \\
\hline Other & 0,0 & 2.1 \\
\hline Do not call the cause of & 0,0 & 6.4 \\
\hline
\end{tabular}

In 2007 "other tasks" and "the absence of the necessity" were named as the most important reasons for not drawing on the CSR reports. In 2009 the same reasons were named, but their rankings are reversed. It is noteworthy that only $26.0 \%$ of managers saw no need for social reporting in 2007 and in 2009 there were $46.8 \%$. We can assume that the worsening economic situation in the country affected the views of managers. But in general, this situation is because the level of businesses management relationship to corporate social responsibility is very unstable. Socially responsible behavior is seen as an attribute of a good life, which can be neglected for the deterioration of the situation. That indicates that the level of understanding of CSR as a strategy is not achieved.

In this regard Russian federal and regional government authorities are taking steps to enhance socially responsible behavior of Russian enterprises.

\section{METHOD OF "STANDARD OF CORPORATE SOCIAL RESPONSIBILITY OF ENTERPRISES OF VORONEZH REGION"}

It should be noted that at the present time in Russia the unified social standard does not exist. So companies could not make up standardized and comparable reporting. All national standards for corporate social responsibility are developed based on the documents of authoritative international organizations: OECD Guidelines for Multinational Enterprises (OECD, 2000); UN Human Rights Norms for Business; Global Compact; ILO Conventions; Global Sullivan Principles. At their base the separate documents, which are advisory in nature, and the fulfillment of their demands is voluntary were formed: Standard "Social responsibility of the organization. Requirements"CSR/2008 developed by Russian Organization for Quality (ROQ, 2007); Standard "Social reporting by enterprises and organizations registered in the Russian Federation. Guidelines", proposed by Russian Chamber of Commerce; "Basic performance indicators. Recommendations for use in the practice of management and corporate nonfinancial reporting", prepared by Russian Union of Industrialists and Entrepreneurs in order to promote the ideas of the Social Charter of Russian Business (2005).

The lack of clear quantitative indicators of CSR and methodological basis for the interpretation of the results are the main problems of the majority of standards. The use of the standards GRI and "Basic performance indicators. Recommendations for use in the practice of management and corporate nonfinancial reporting" (Russian adaptation of the GRI) can help to overcome these problems (Prokopov and Feoktistova, 2008). But first of all they do not allow 
evaluation of results of social activity without the involvement of experts, as they do not have specific guidelines for the indicators. Secondly, the composition of the proposed indicators of activity fits only to a large industrial enterprise. And thirdly, they give rise to only a formalization of the reporting process in the management of CSR. Also, the general purpose of each standard is not reduced to the common goal: one can assess the quality of the preparation of social reports, while others are designed to improve the quality of reporting on sustainable development, the third are made for stakeholders.

In the last 2-3 years in the Russian regions some steps to enhance socially responsible behavior of regional companies have been taken. This process was developed by such tools as organization of the various competitions, building a rating of socially responsible businesses, and developing their own CSR standards and codes. In the Voronezh region the initiative in the introduction and development of CSR has also been taken. We have developed "Standard of corporate social responsibility of enterprises of Voronezh Region". It covers the general theoretical position associated with the terminology, goals, principles of corporate social responsibility, and includes minimum required indicators to assess the level of social responsibility. The standard can be used by organizations of all sizes and types, regardless of affiliation to a particular industry, the level of knowledge of the requirements of international standards for selfassessment and provided information to key stakeholders (public authorities and management bodies of local self-government, community organizations, made available to the public through media, etc.).

The Standard provides the use of both quantitative and qualitative indicators. The use of quantitative variables ensures comparability of data. The principal feature of this standard is that the CSR indicators are grouped in three spheres of responsibility - technical-technological, organizational-economic and non-productive. This allows description of three areas of socio-economic relations:

- State of the productive forces, from which all other components of socially responsible behavior of the enterprise depend on;

- The degree of organizational and economic relations, which mediate the productive forces;

- The nature and intensity of interaction of companies with governments, local governments, civil society organizations in decision of a wide range of socially significant issues of nonproductive activities.

For example, composition of the indicators in the organizational-economic sphere is presented in Table 4.

The structure of the indicators in the Standard shows not only content elements of the specific areas of CSR, but also evaluates the level of achievement in this area.

\section{INTERPRETATION OF THE RESULTS OF CORPORATE SOCIAL RESPONSIBILITY FOR THE COMPANY AND ITS STAKEHOLDERS}

Standard's indicators rank the activities of the company's corporate social responsibility at three levels. Ranking done on the basis of the implementation obligations of socially responsible activities: mandatory and voluntary. The minimum value of the indicator sets a limit of mandatory level.

Failure to comply with mandatory actions automatically precludes the company from a number of responsible, no matter what voluntary socially important transactions it may produce. In the presence of at least one indicator with a value of "zero", the enterprise cannot be considered socially responsible. This is due to the fact that in prescribing regulations the values that society considers unconditional are reflected. The company may not share this value system, but has no right (either legal or moral) to consider their own values more significant than that prescribed by society. This does not exclude the possibility to initiate the introduction of changes to regulations aimed at improving the social responsibility of all society that can be considered as an element of socially responsible behavior on a higher - voluntary level.

The Standard takes into account that the conditions in which businesses operate are specific to each region. Achievement of at least average level indicates that the enterprise-specific parameter of its activities is working "better than others." Therefore, the averages over sphere of activity in Voronezh region were taken as the first level of CSR.

The first level is primary. It represents the company's activities aimed at the assimilation of the CSR provisions which are already developed, obtaining a sufficiently common for companies in the region results and the adaptation to the generated rules. So it can be treated as a voluntary adaptive. 
Table 4: Indicators of corporate social responsibility in the organizational-economic sphere

\begin{tabular}{|c|c|c|c|c|}
\hline № & Name of indicator & $\begin{array}{l}\text { The minimum value of } \\
\text { the indicator not } \\
\text { reached ( } 0 \text { points) }\end{array}$ & $\begin{array}{c}\text { The minimum value of } \\
\text { the indicator } \\
(1 \text { point })\end{array}$ & $\begin{array}{l}\text { The recommended } \\
\text { value of the indicator } \\
\text { ( } 2 \text { points) }\end{array}$ \\
\hline 1 & Collective agreement & $\begin{array}{l}\text { The collective } \\
\text { agreement is not } \\
\text { concluded }\end{array}$ & $\begin{array}{l}\text { The collective } \\
\text { agreement is concluded }\end{array}$ & $\begin{array}{l}\text { The collective agreement } \\
\text { is tailored to a tripartite } \\
\text { agreement between the } \\
\text { Government of the } \\
\text { Voronezh region, trade } \\
\text { unions and employers' } \\
\text { associations }\end{array}$ \\
\hline 2 & $\begin{array}{l}\text { Average monthly wage } \\
\text { (rubles per } 1 \text { employee) }\end{array}$ & $\begin{array}{l}\text { Below the average } \\
\text { value in the region by } \\
\text { activity }\end{array}$ & $\begin{array}{l}\text { Average value in the } \\
\text { region by activity and } \\
\text { higher }\end{array}$ & $\begin{array}{l}\text { Average value in } \\
\text { Russia by activity and } \\
\text { higher }\end{array}$ \\
\hline 3 & $\begin{array}{l}\text { The minimum wage in the } \\
\text { organization (rubles per } \\
\text { month) }\end{array}$ & $\begin{array}{l}\text { Below the living-wage } \\
\text { established in the } \\
\text { region }\end{array}$ & $\begin{array}{l}\text { The living-wage } \\
\text { established in the } \\
\text { region and higher }\end{array}$ & $\begin{array}{l}\text { Double living-wage } \\
\text { established in the } \\
\text { region and higher }\end{array}$ \\
\hline 4 & $\begin{array}{l}\text { The coefficient of wage } \\
\text { differentiation in the } \\
\text { organization (the ratio of } \\
\text { average wages } 10 \% \text { of the } \\
\text { highest paid and the average } \\
\text { wage of } 10 \% \text { of the lowest paid } \\
\text { employees (how many times)) }\end{array}$ & $>10$ & $5-10$ & $<5$ \\
\hline 5 & $\begin{array}{l}\text { Payment and adjustment of } \\
\text { wages }\end{array}$ & $\begin{array}{l}\text { With arrears of wage } \\
\text { during the year }\end{array}$ & $\begin{array}{l}\text { Without arrears of } \\
\text { wages }\end{array}$ & $\begin{array}{l}\text { Indexation of wages in } \\
\text { accordance with the } \\
\text { consumer price index in } \\
\text { the region }\end{array}$ \\
\hline 6 & $\begin{array}{l}\text { The coefficient of staff } \\
\text { turnover }(\%)\end{array}$ & $>20$ & $10-20$ & $<10$ \\
\hline 7 & $\begin{array}{l}\text { Number of employees, passed } \\
\text { vocational training, retraining } \\
\text { and advanced training at the } \\
\text { expense of the employer during } \\
\text { the year (\% of average number } \\
\text { of employees) }\end{array}$ & $<10$ & $10-20$ & $>20$ \\
\hline 8 & $\begin{array}{l}\text { Saving workplaces (\% of } \\
\text { workplaces at the beginning } \\
\text { of the year) }\end{array}$ & $\begin{array}{l}\text { Reduction } \\
\text { (more than 5\%) }\end{array}$ & $\begin{array}{l}\text { On last year's level }(+/ \\
-5 \%)\end{array}$ & $\begin{array}{l}\text { Increase } \\
\text { (more than 5\%) }\end{array}$ \\
\hline 9 & Violations of tax laws & $\begin{array}{l}\text { Tax penalties have been } \\
\text { applied }\end{array}$ & $\begin{array}{l}\text { Tax payments are paid in } \\
\text { full value at the request of } \\
\text { the tax authority within } \\
\text { the period when the duty } \\
\text { on the application of } \\
\text { penalties by the tax } \\
\text { authority has not yet } \\
\text { begun }\end{array}$ & $\begin{array}{l}\text { Tax payments made } \\
\text { promptly and in full } \\
\text { value }\end{array}$ \\
\hline 10 & $\begin{array}{l}\text { Violations of Charter and } \\
\text { contractual obligations to } \\
\text { suppliers of material and } \\
\text { financial resources (including } \\
\text { owners) }\end{array}$ & $\begin{array}{l}\text { Violations were not } \\
\text { resolved or resolved in } \\
\text { the courts }\end{array}$ & $\begin{array}{l}\text { Violations resolved out } \\
\text { of court }\end{array}$ & No violations \\
\hline 11 & $\begin{array}{l}\text { Cases of unreasonable } \\
\text { overpricing }\end{array}$ & $\begin{array}{l}\text { Cases of unreasonable } \\
\text { overpricing were } \\
\text { officially registered }\end{array}$ & No violations & $\begin{array}{l}\text { Socially oriented } \\
\text { pricing policy } \\
\text { (discounts, benefits for } \\
\text { disadvantaged groups, } \\
\text { etc.) }\end{array}$ \\
\hline
\end{tabular}

The second level of CSR in the standard is recognized not only voluntary, but the initiative in its distribution. Therefore, companies' own initiatives and results in the field of CSR, which mark out a particular company of their total population, are especially highlighted. The excess of 
the actual values of indicators established in the region and the best business practice results are assigned as the parameters of the second level of CSR. Naturally, the adoption of the second level involves the achievement of the first. If the first level of corporate social responsibility is not reached by the values of a particular indicator, then the company cannot claim to second level on the same indicator.

Indicators laid down in the Standard, provide a methodological basis for self-assessment company in CSR issues. For example, to this end, we propose the use of "traffic light corporate social responsibility", which is a matrix in which the results of activities in spheres of responsibility and stakeholder are engaged. The value of the resulting indicator in a certain sphere of corporate social responsibility (technical-technological, organizational-economic, non-production) is determined for each stakeholder. The values range from 0 to 2 and is calculated in two steps:

1. The value of the indicator $R_{i}^{j}$ (i - element of the Sphere of corporate social responsibility, j Stakeholder) is determined by comparing the actual value for the reporting period with the established standards (the minimum allowed value of the indicator, which determines a level of responsibility, and recommended the indicator value corresponding to the two level responsibility):

$$
R_{i}^{j}=\left\{\begin{array}{l}
0, \text { if the actual value }<\text { the norm of the first level } \\
1, \text { if the actual value } \geq \text { the norm of the first level } \\
2, \text { if the actual value } 2 \text { the norm of second level }
\end{array}\right.
$$

2. The resulting indicator $\mathrm{R}^{\mathrm{j}}$ reflects the status of certain Sphere of corporate social responsibility for the j-th Stakeholder:

$$
R^{j}= \begin{cases}\frac{\Sigma_{i=1}^{n} B_{i}^{j}}{n}, & R_{i}^{j} \neq 0 \\ 0, & R_{i}^{j}=0\end{cases}
$$

The resulting indicator gives three types of signals: - Exit from the zone of responsibility $\left(\mathrm{R}^{\mathrm{j}}=0\right)$ "red";
- Being in the middle zone of responsibility $\left(\mathrm{R}^{\mathrm{j}}\right.$ $\in[1 ; 2))$ - "yellow";

- Leadership responsibility $\left(\mathrm{R}^{\mathrm{j}}=2\right)$ - "green."

As a result, the company can create a results matrix for spheres of responsibility and stakeholders, presented in Table 5. In each cell of the matrix the resulting calculated value is stored in a specific indicator for each CSR stakeholders, showing three types of signal: output from the zone of responsibility, being in the middle zone of responsibility and leadership responsibility.

Table 5: The results matrix of corporate social responsibility

\begin{tabular}{|l|c|c|c|c|}
\hline Sphere of CSR & Stakeholder 1 & Stakeholder 2 & Stakeholder 3 & Stakeholder j \\
\hline $\begin{array}{l}\text { Technical- } \\
\text { Technological }\end{array}$ & $R_{T T}^{1}$ & $R_{T I}^{2}$ & $R_{T T}^{3}$ & $R_{T T}^{j}$ \\
\hline $\begin{array}{l}\text { Organizational- } \\
\text { Economic }\end{array}$ & $R_{O E}^{1}$ & $R_{O E}^{2}$ & $R_{O E}^{3}$ & $R_{O E}^{j}$ \\
\hline $\begin{array}{l}\text { Non- } \\
\text { Productive }\end{array}$ & $R_{N P}^{1}$ & $R_{N P}^{2}$ & $R_{N P}^{3}$ & $R_{N P}^{j}$ \\
\hline
\end{tabular}

Bearing in mind that the content of corporate social responsibility reflects the expectations of society at a particular time and is constantly changing along with the problems of society and its expectations. Therefore, the provisions of the Standard, the composition and the quantitative values of the indicators of corporate social responsibility are subject to periodic review.

\section{REFERENCES}

. Social Charter of Russian business (in Russian). (2005). Moscow, RU: The Russian Union of Industrialists and Entrepreneurs (RSPP).

. Social reporting companies and organizations registered in the Russian Federation (in Russian). (2005). Moscow, RU: Standard RF Chamber of Commerce. GRI. (2011). Sustainability Reporting Guidelines (Report). from Global Reporting Initiative (GRI) 
https://www.globalreporting.org/resourcelibrary/G3.1Guidelines-Incl-Technical-Protocol.pdf

Mamic, I. (2003). Business and code of conduct implementation. How firms use management systems for social performance. from International Labour Organization http://www.ilo.org/images/empent/static/mcc/downloa d/supply_chain.pdf

Nikitina, L. M. (2009). Corporate social responsibility as a system of socio-economic relations (in Russian). Voronezh, RU: VSPU.

OECD (Ed.). (2000). The OECD Declaration and Decisions on International Investment and Multinational Enterprises: Basic Texts (OECD
Declaration and Decisions ed.): OECD. Directorate for Financial, Fiscal and Enterprise Affairs.

Committee on International Investment and Multinational Enterprises.

Prokopov, F., \& Feoktistova, E. (2008). Basic indicators of performance. Recommendations for use in the practice of governance and corporate non-financial reporting (in Russian). In A. N. Shokhin (Ed.). RSPP: Moscow, RU.

ROQ (Ed.). (2007). Social responsibility of the organization. Requirements (in Russian) (Standard ed.). Moscow, RU: Russian Organization for Quality 